Agricultural Journal 14 (6): 123-131, 2019

ISSN: 1816-9155

(C) Medwell Journals, 2019

\title{
Process Production, Physico Chemical and Sensory Attributes of Pelpeledgi; A Cameroonian Fermented Fish Product
}

\author{
${ }^{1}$ Hamadou Oumarou, ${ }^{1}$ Salamatou Mohamadou, ${ }^{2}$ Mahama Abdoulaye, \\ ${ }^{1}$ Djoulde Darman Roger and ${ }^{3}$ Francois Xavier Etoa \\ ${ }^{1}$ National Advanced School of Engineering of Maroua, University of Maroua, \\ P.O. Box 46, Maroua, Cameroon \\ ${ }^{2}$ Institut Universitaire de Technologie, University of Ngaoundere, \\ P.O. Box 454, Ngaoundere, Cameroon \\ ${ }^{3}$ Faculty of Sciences, University of Yaoundé I, P.O. Box 33 Yaoundé, Cameroon
}

\begin{abstract}
The Pelpeledgi is a fermented fish product consume in central African countries. A survey was done to assess sociocultural value and how it's process. Some physicochemical characteristics, microbiological profile and sensorial attributes were also evaluated. It was found that this product is largely produce and consumed in the area as traditional dish. Process technology is transmitted toward generation from parents to children. Process steps of Pelpeledgi involve catching, washing, gutting, paring, evisceration, spontaneous fermentation during 6-48 $\mathrm{h}$ depending of seasons and drying for 3-5 days. None salting step was noted. $\mathrm{pH}$ of Pelpeledgi samples range from 6.80-8.41. Salt content and moisture range from $2.42-3.38 \%$ and from $10.22-19.11 \%$. Concerning microbiological characteristics, total microbial count was high in all samples ranging from 6.41-7.70 log cfu/g. lactic acid floras and Bacillus seems to be the predominant flora of Pelpeledgi. Lactic flora and Bacillus load of Pelpeledgi ranging from 4.57-5.28 log cfu/g and from 3.47-4.85 log cfu/g, respectively. Yeast and moulds ranging from 3.06-3.10 log cfu/g, E. coli was present in certain samples, ranging from 1.23-1.70 log cfu/g and no Salmonella were detected. Staphylococcus aureus and total coliform were present in all samples, ranging from 1.75-2.65 log cfu/g and 3.82-4.85, respectively which is a potential risk for consumer. Thus, the fish product is microbiologically unsafe. Sensory analyses shows that samples from Blangoua are most appreciated with positive correlation between total microbial count and sensory attributes. Despite of microbiological diversity and sensorial attributes, efforts are needed to improve Pelpeledgi process through HACCP and use of starter culture with interesting technological properties to obtain better product for the public consumption.
\end{abstract}

Keys words: Pelpeledgi, fermented fish, Hydrocynus forskalis, Cameroon, HACCP

\section{INTRODUCTION}

Fish contribute to food security in many regions of the world, providing a valuable supplement for diversified and nutritious diets (Bene and Heck, 2005). Poor people in developing countries tend to depend, essentially on carbohydrate-based diets for their nutritional intake which are relatively low in protein and micronutrients (Singh and Sharma, 2018). In this context, fish can play a particularly important role in combating micronutrient deficiencies as they contain high quality protein, essential fatty acids and also key micronutrients such as vitamin A, iron, calcium, zinc and iodine (Loring et al., 2019). In terms of protein, it is recognized that in Low-Income Food-Deficit (LIFD) countries the main sources of protein comes from plants such as rice, maize or cassava (FAO., 2009). However, as pointed out by Kawarazuka and Bene (2010) in some conditions fish can be a far more efficient source of protein than any other food for the poor, due in particular to their accessibility, availability and digestibility. While the digestibility of foods derived from plants is very poor compared to those derived from animals, among the latter, fish is one of most affordable and accessible sources (Bose and Dey, 2007). Northern Cameroon is the largest artisanal and continental fishery zone of central African countries. This is a vital source of food income for local populations. However, access to fresh fish within the area to local population is limited (Feka and Manzano, 2008). This is due to lack of preservation resource which involve more financial resources (Sefa-Dedeh, 1995; Gram and Huss, 2000). As fish are highly perishable it's advisable to process it immediately after capture in order to conserve its nutritional properties and extend its shelf-life by smoking or thorough fermentation. Because of rampant extreme poverty within the region, local population opted for

Corresponding Author: Hamadou Oumarou, National Advanced School of Engineering of Maroua, University of Maroua, P.O. Box 46, Maroua, Cameroon 
consumption of accessible and cheapest fish in rank of them fermented and or dried fish (Feka and Manzano, 2008). Add to this, there is a lack of modern fisheries industries facilities within the region, so, artisanal small scale fisheries unit are widely used to process fish (Chiwaula et al., 2011). This traditionally method is generally in poor hygienic conditions, bad storage and the final poor quality product (Noman et al., 2019; Rousseau et al., 2019). In African countries, fermented fish are common but very few information concerning these fish product exist in Cameroon. Pelpeledgi is one among fermented fish product of Northern Cameroon. In literature, there is no information about process technology of Pelepeldgi or its microbial profile and sensory attributes. This study, thus, aims at contributing to fill this scientific gap while providing useful data Pelpeledgi to eventual interested industries.

\section{MATERIALS AND METHODS}

Survey: The survey concerned consumers and processors of Northern region of Cameroon, specifically, we clustered some districts were the product are widely used and process within the sub region. The design of the questionnaire was mainly based on the objectives of this research, its development has followed the logic of the funnel as described by Bergadàa and Nyeck. The resulted tables of the indicators were then converting into questionnaire for inquiries about social and cultural status: age, sex, marital status, educational level of consumer or processor; the level of knowledge, consumption, estimation grade and artisanal technology for processing of Pelpeledgi.

Survey area: Survey area was the septentrional region of Cameroon. Interviews were done in general in local language Fulany, Arabic, Massa, Musgum... official languages (English and French) were also used at urban area in market.

Sampling: Samples were purchased on markets and on processors within clustered area. These areas were chosen according to their activities related to Pelpeledgi. While Yagoua is known as potential fishing zone we didn't find necessary to collect sample there as local population prefer fresh fish and do transform only for commercial purpose. Samples area were then Maga and Pouss $\left(10^{\circ} 8022 \mathrm{E} ; 1^{\circ} 9592 \mathrm{~N}\right)$ in Mayo Danay; Lagdo $\left(13^{\circ} 4014 \mathrm{E} ; 9^{\circ} 0257 \mathrm{~N}\right)$ in Benue and Blangoua $\left(14^{\circ} 3449 \mathrm{E}\right.$; $12^{\circ} 4457 \mathrm{~N}$ ) in Lac Chad. Collected samples were kept in cooler filled with ice-cold and transported rapidly to laboratory for biochemical and microbiological analysis.

Physicochemical analysis: Only eighteen of fifty four samples of Pelpeledgi collected on market and processor were randomly selected for analysis. Moisture was analyzed employing AOAC. (2000) (Association of Official Analytical Chemist Procedures). The $\mathrm{pH}$ of the homogenized samples was measured with a $\mathrm{pH}$-meter Model Hm 305 (TOA Electronic, Japan). Salt content was determined according to the method of (Yankah et al., 1993). About $0.5 \mathrm{~g}$ of Pelpeledgi was digested in a stomacher with $20 \mathrm{~mL}$ of concentrated $\mathrm{HNO}_{3}$ for $2 \mathrm{~h}$ at $100^{\circ} \mathrm{C}$ on cooling, $100 \mathrm{~mL}$ water and $5 \mathrm{~mL}$ of ammonium iron sulphate indicator were added and the salt content was determined by titration with a solution of $0,1 \mathrm{M}$ $\mathrm{AgNO}_{3}$ which was previously standardized using $0,1 \mathrm{M}$ standard $\mathrm{KCl}$ solution. Water Activity $\left(\mathrm{A}_{\mathrm{w}}\right)$ was measured using a water activity meter FA-ST/1 (GBX Scientific instruments).

Microbiological analyses: About $10 \mathrm{~g}$ of Pelpeledgi samples were suspended in $90 \mathrm{~mL}$ of sterile 0,1 peptone and homogenized in a stomacher (Lab Blender, Model 80, Seward Medical, London) for 3 min at "normal speed". The homogenates were used for all the microbiological analyses. Suitable decimal dilutions were pouring plated on PCA (Difco) for total microbial count, MRS for Lactic acid bacteria, PDA+chloremphenicol (Difco) for yeasts and moulds, mannitol for Staphylococcus aureus, Glucose Agar with Bromocresol Purple (BCP) for spore of Bacillus after heat treatment of the samples ( $15 \mathrm{~min}$ with $80^{\circ} \mathrm{C}$ ), EMB for total coliform, XLD for Salmonella sp. and TBX for E. coli. Inoculated petri dishes were incubated at $25-44^{\circ} \mathrm{C}$ for 24-72 h (Table 1).

Sensory evaluation: Sensory analysis was carried out on Pelpeledgi samples from different clustered area. A sample of each area was submitted to a panel made up of 20 people (12 men and 8 women) from 18-45 years old, selected on the basis of their frequent use (use of

Table 1: Plating condition used for the screening of different microflora

\begin{tabular}{|c|c|c|c|}
\hline Flora & Culture medium and references & Incubation temperature $\left({ }^{\circ} \mathrm{C}\right)$ & Incubation time (hours) \\
\hline Total mesophilic flora & PCA (Merk) & 30 & 48 \\
\hline Lactic flora & MRS (AES laboratoire) & 30 & 48 \\
\hline Spore of Bacillus & Glucose agar+BCP (AES laboratoire) & 30 & 48 \\
\hline Yeasts and mould & PDA+Chloramphenicol & 25 & 2-5 days \\
\hline Salmonella sp. & XLD & $24-48$ & 37 \\
\hline Staphylococcus aureus & Mannitol & 37 & $24-48$ \\
\hline Total coliforms & VRBL (Merk) & 30 & 24 \\
\hline E. coli & TBX & 44 & 24 \\
\hline
\end{tabular}


Pelpeledgi at least 3 time on week) and continuous use (consumption, since, the childhood). Quantitative Descriptive Analysis (QDA) 21 was used to determine attributes of samples (Yang and Lee, 2019). A 9 points hedonic scale was used and only one characteristic was evaluated at the same time. The tasters were held to rinse their mouth after each elementary tasting before the sample, according to a definite order.

\section{RESULTS AND DISCUSSIONS}

Physical presentation of 'Pelpeledgi": The Pelpeledgi was found to be small aggregates of almost small size fish, usually of a gray to yellow color with a strong odor of putrefaction (Fig. 1). This is usually use as main course in typical dish of local population. However, it can also be used as aromatic or condiments for soup dishes for urban meals.

Social importance of Pelpeledgi: In total, 455 people were interviewed among consumers and processors. The actors in the sector of Pelpeledgi processing are numerous. Fishermen ensure the quest of the raw material by fishing and deliver it to the processors. The latter ensure all the operations of the processing (evisceration, trimming, fermentation, drying). Most of them are Cameroonian (90\%), (80\% women and 10\% men) against $10 \%$ Foreign men from countries such as Mali, Tchad and Nigeria. The workforce is made up of man for fishing and women for processing. It is important to note that the few men involved in processing system are employees or direct family of women involve in transformation process. We also notice the presence of men involve in processing activities when it was a organize groups like cooperatives members and owners of the means of production. Among other things, this man ensures handling, supply, cutting, packaging, cleaning and disinfection of processing sites.

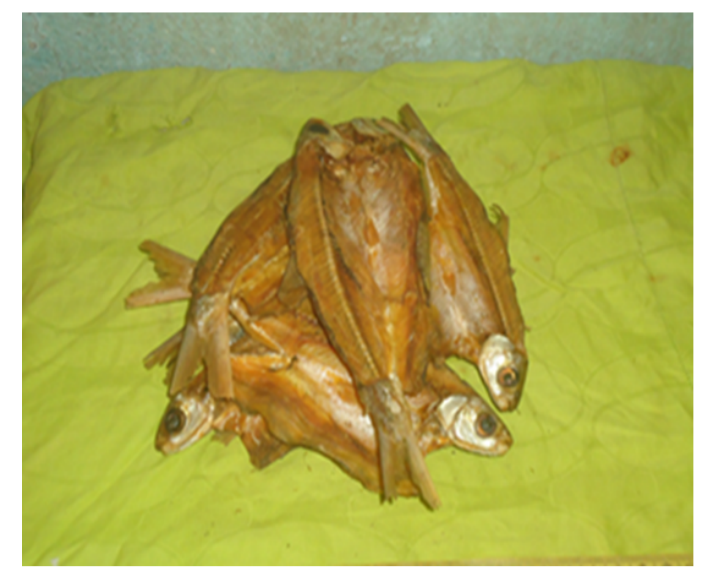

Fig. 1: Sun-dried fermented fish locally name Pelpeledgi
We also notice the presence of traders which are collectors or wholesalers and retailers or negotiators "dilaali". They come from local markets in the interior of the country (Adamaoua or Southern of Cameroon) and sometimes even in the sub-region (Chad, Niger and Nigeria). They are responsible for the wholesale and/or retail sale of the product. Finally, consumers from big towns of the region are the final recipients whose demand is an important and decisive for processing activity.

About 85.91\% of interviewers know Pelpeledgi. Those who didn't know the fish product are young in general ( $<25$ years old) and most are from rich families who can afford and accommodate beef meat all the time for their daily meals. Those young adults seem to grow in environment without this type of product, so, they ignore apparently virtues of these African fermented products. Regarding sex and ethnic group, there is no relationship between knowing Pelpeledgi and gender but we observe a link between ethnic group and knowledge of Pelpeledgi. Tribes of Northern Cameroon are those who know more this product. Almost most of those who know Pelpeledgi say to consume it (92.05\%). This fermented fish is a part of these populations diet. Like noted previously, young are those who mostly didn't consume Pelpeledgi. Some adults who exceptionally indicate to dislike and not consume the Pelpeledgi are those which do not consider all fish product in their diet say to present fish and fish product intolerance. Most of those who consume Pelpeledgi have it at daily basis in their meal (62.07\%). The explanation of this is that the Pelpeledgi meals are cheap protein source and can be used in soup without condiment because of its strong odor and taste.

The Pelpeledgi market: The Pelpeledgi is produced around Lake Chad, notably in South of Chad, the far North, North and North East of Cameroon. The largest production units are located in the vicinity of the main landing zones throughout the Northern part of Cameroon, particularly in the regions of Maga, Maroua and Garoua. The business analysis of the Pelpeledgi sector indicates that it's also obeys to the law of supply and demand. The selling price which varies between 1,000 and 3,000 CFA francs per kilogram is a function of the seasons (high prices during raining season), the nature of the fish species involve (one or more specie), the landing sites and finally the unfair competition of national collectors or foreigners. The Pelpeledgi's global offer is intended on the one hand for the local market controlled by local distributors (dillalis) or retailers and on the other hand on the external market managed mainly by wholesalers or collectors from neighboring countries. At the national level, processed products are marketed in descending order in the regions of Maroua, Yagoua, Kousseri, Mora, Mokolo, Garoua, Figuil. Most of the export flows of these products are directed to the countries of the sub region 
(a)

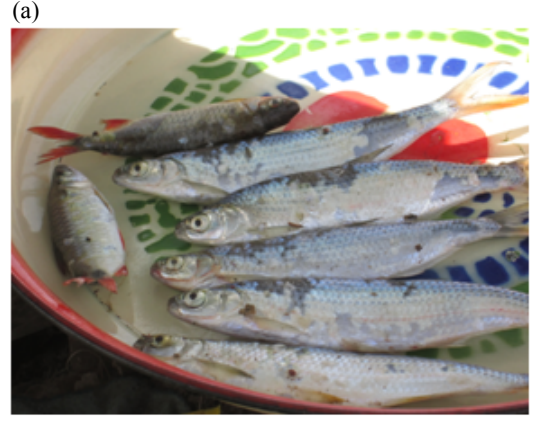

(c)

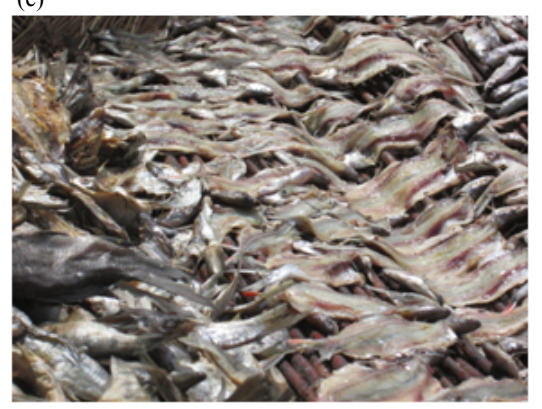

(b)

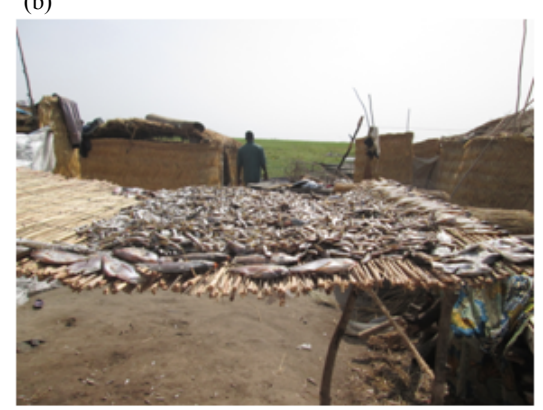

(d)

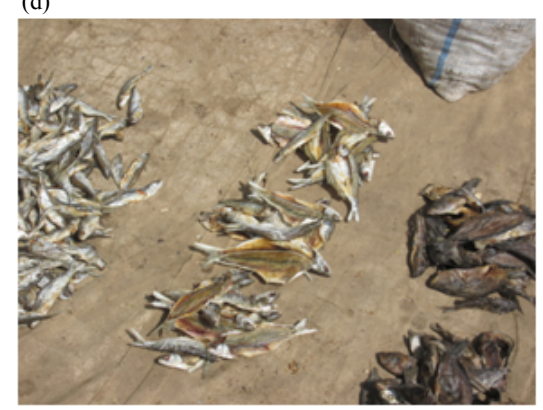

Fig. 2(a-d): (a) Hydrocynus forskalis specie use to produce Pelpeledgi, (b) drying some fishes without gutting Pelpeledgi, (c) drying Pelpeledgi on shed and (d) Pelpeledgi on market exhibited on simple bags

(Chad, Niger, Nigeria and Soudan). The largest importer of Pelpeledgi is Chad, followed by Nigeria. It should be noted that these quantities do not take into account informal flows which account for the majority of exports from neighboring countries. We were told that there's informal European destination also. Somme European population mainly originating from Northern Cameroon and Chad are also amongst consumer. Usually destinations registered for the European market are Italy, France and Belgium. This market, although full of many Africans and Asians is not a big demand for this product despite many initiatives of private exporters. The quality of the product constitutes a serious obstacle to its access to European market.

\section{Production techniques of Pelpeledgi}

Pelpeledgi's fish species: It is essential to note that Pelpeledgi processing involve only one fish species, namely Hydrocynus forskalis (Fig. 2a). This is one of the difference we found comparing to other African fermented fish products which are produce using many fish species (Essuman, 1992). Some processors, to enhance quantity of fermented fish can rather mix with Hydrocynus vittatus a close subspecies of Hydrocynus forskalis. This is said to mainly lead to a bitter taste of final "Pelpeledgi". About $80 \%$ of consumers appreciate the Pelpeledgi for its flavor but generally prefer fish from Hydrocynus forskalis fish species. It was told by processor that some attempt to use other species such as Galeoides decadactylus or false captain and
Pseudotolithus brachygnatus or captain for their high organoleptic quality lead to a product different from "Pelpeledgi" with none were ready to purchase. Previously, Pelpeledgi was consumed only by rural households. Nowadays with the current situation, it is often used as a substitute for fresh fish in urban areas and even in some European countries as mentioned earlier. According to the survey results, 93\% of surveyed households consume this commodity. Pelpeledgi process (Fig. 3) is transmitted from parents to children through generation. Figure 3 present flow diagram process of Pelpeledgi. This was established as describe by producer during our survey. This processing method does not depend to area zone, sometime, processor of same area have variable technology process (Fig. 3).

Production diagram: The production technique of the fermented and dried fish described by the interviewers is almost identical (Fig. 3). Two manufacturing methods have been widely described by processors as commonly used methods: the fermentation of small whole fish follow by sun drying and the fermentation of very small size fish followed by smoking. However, only the first method is used for commercial "Pelpeledgi" the second process is mainly use for family kitchen. The process of making the "Pelpeledgi" consists of several steps shown in Fig. 3. Raw material supply: after bringing the fish back to the river side, it is first washed with river water. 
Agric. J., 14 (6): 123-131, 2019

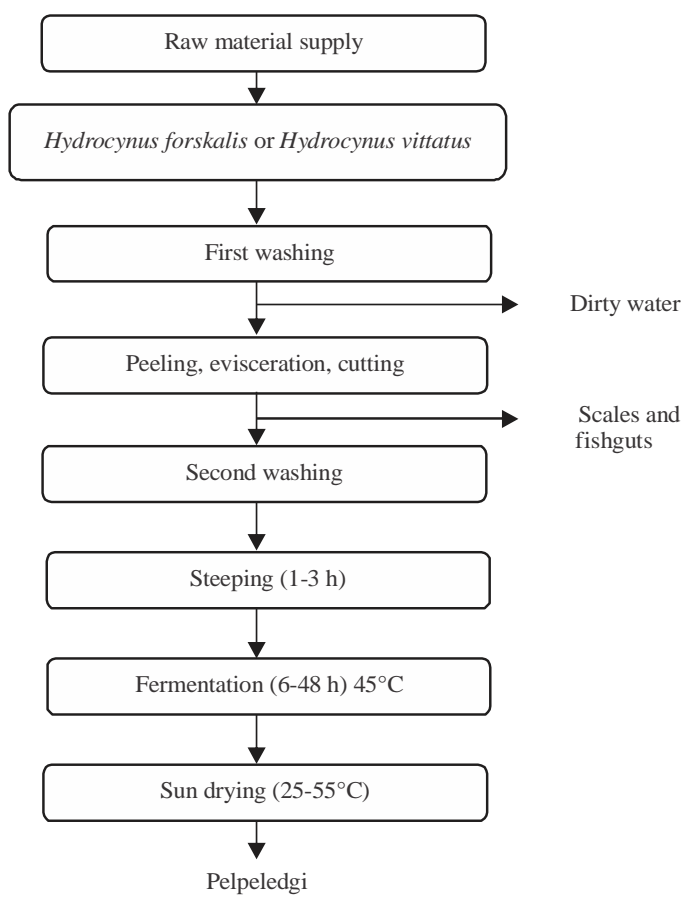

Fig. 3: Flow diagram of Pelpeledgi traditional process technology

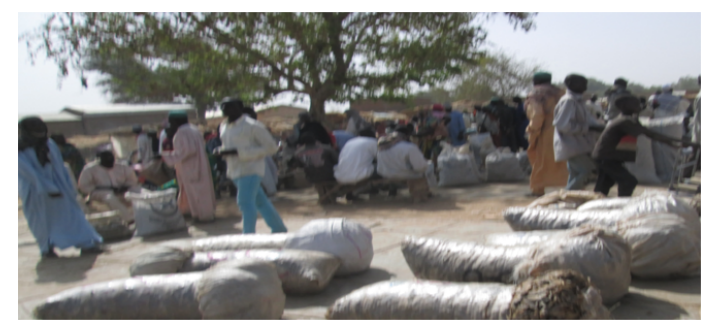

Fig. 4: Storage of Pelpeledgi into polyethylene plastic bags

Washing: The next step of the process is draining and evisceration of fish (Fig. 3). Once landed, the fish is grounded and transported in small vans or carts to the production site. The fish undergoes a preliminary trimming (peeling, evisceration, cutting ...) with a knife. The eviscerated fish is then rinsed once more with river water.

Steeping and fermentation: The next step is natural steeping for few hours followed by fermentation (Fig. 2c). The fermentation is done in different types of materials (tanks or bucket in cement, cans, basins, jars ...). It is spontaneous and consists of a simple incubation of raw fish at optimal temperatures that can reach or exceed $45^{\circ} \mathrm{C}$. The fermentation time is not standardized and varies from 6-48 h (2 days according to processor when cool period).
Drying: The next day the fermented fish is sun dry for 3-5 days (Fig. 2b). Drying it is done traditionally on ronier wooden racks (Fig. 2), nets of recovery, mats, herbs or on the ground and in open sky (Fig. 2c). The fish is left to dry for 2-4 days. It's returned once a day (at midday), stacked and covered with plastic sheeting held by stones before sunset. Some processors say to skip the fermentation step; however, majority (97.57\%) reported to avoid doing this as end product texture become pastier like. It is essential to underline that there is not salting step noticed during process. None of processor indicates to add salt at any time during the process. Thus, Pelpeledgi could be classified as salt free fermented fish product (Sanni et al., 2002).

Packaging: The end product are then pack in reused polyethylene plastic bag (Fig. 4) to facilitate it's transportation to the local market and its storage.

The Pelpeledgi meal: Pelpeledgi is in general cook with dried or green leaves and maize or millet meal, rarely with rice. A negligible proportion of population eats the fermented fish with yams or potato. Those who consume this without any accompaniment are mainly from fisher's ethnics groups like Massa, Musgum and Kotoko tribes. Some people from West Africa was found to be Pelpeledgi processor, they said to come mainly from Mali. This result shows that there are foreigners among fisher in Cameroon. The product is consumed in different forms with tubers, leaves or alone till it is an exception. Excepting fisher's families, obtaining of Pelpeledgi is buying. The reason concerning of appreciation of Pelpeledgi is primary odor of the product, then taste, texture and color of the African fermented fish. Those who dislike Pelpeledgi declared a bitter taste. According to Belitz et al. (1979), bitterness of fermented fish is due to inadequate fermentative conditions causing high oxidation of fat during process technology. Indeed, the presence of peptides composed of amino acids with a hydrophobic structure and the oxidation of the lipids (Belitz et al., 1979) are responsible for bitterness. Hydrophobic amino acid side chains provoke bitterness of peptides which is independent from the amino acid sequence. Matoba and Hata (1972) explained in their studies how bitterness is developed by hydrolyzing non-bitter protein molecules.

Physicochemical characteristics: The results of physicochemical analyzes performed on Pelpeledgi samples collected in local markets and at the processing and sale sites are summarized in Table 2 .

$\mathrm{pH}$ of samples ranging from 6.88-7.79. There is a significant difference between samples of different areas and also within same area. This $\mathrm{pH}$ is high in all samples areas. High pH may be due to nitrogen basic compound 
Agric. J., 14 (6): 123-131, 2019

Table 2: $\mathrm{pH}$, salt content, moisture and $\mathrm{A}_{\mathrm{w}}$ of Pelpeledgi samples from different areas

\begin{tabular}{lllll}
\hline Different areas & $\mathrm{pH}$ & Salt content & Moisture & $\mathrm{A}_{w}$ \\
\hline Maga $(\mathrm{n}=6)$ & $7.91^{\mathrm{a}} \pm 0.82$ & $2.42^{\mathrm{a}} \pm 0.53$ & $16.22^{\mathrm{b}} \pm 6.97$ & $0.73^{\mathrm{b}} \pm 0.02$ \\
Pous $(\mathrm{n}=3)$ & $8.41^{\mathrm{b}} \pm 0.03$ & $2.81^{\mathrm{a}} \pm 0.9$ & $19.11^{\mathrm{b}} \pm 2.01$ & $0.76^{\mathrm{b}} \pm 0.02$ \\
Lagdo $(\mathrm{n}=6)$ & $6.85^{\mathrm{a}} \pm 0.16$ & $3.37^{\mathrm{b}} \pm 0.14$ & $10.22^{\mathrm{a}} \pm 4.51$ & $0.72^{\mathrm{ab}} \pm 0.05$ \\
Blangoua $(\mathrm{n}=3)$ & $6.80^{\mathrm{a}} \pm 0.14$ & $3.38^{\mathrm{b}} \pm 0.27$ & $17.66^{\mathrm{b}} \pm 5.18$ & $0.70^{\mathrm{a}} \pm 0.02$ \\
\hline
\end{tabular}

Table 3: Microbiological profile of Pelpeledgi

\begin{tabular}{|c|c|c|c|c|c|c|c|c|c|c|c|c|c|c|c|c|}
\hline \multirow[b]{2}{*}{ Variables } & \multicolumn{4}{|c|}{ Maga $(n=6)$} & \multicolumn{4}{|c|}{ Pous $(n=3)$} & \multicolumn{4}{|c|}{ Lagdo $(\mathrm{n}=6)$} & \multicolumn{4}{|c|}{ Blangoua $(n=3)$} \\
\hline & Min. & Max. & Mean & SD & Min. & Max. & Mean & SD & Min. & Max. & Mean & SD & Min. & Max. & Mean & SD \\
\hline FAM (log cfu/g) & 5,5 & 7.7 & & 0.81 & & & & 1.18 & & & 6.50 & 0.59 & & .71 & 7.7 & 0.01 \\
\hline acil & & 4.4 & 3.82 & 0.68 & & 4.9 & 4.85 & 0.11 & 4.78 & 4.95 & 4.84 & $0 .($ & 3.29 & 3.65 & 3.47 & 0.25 \\
\hline $\mathrm{u} / \mathrm{g})$ & 4.23 & 5.36 & 4.87 & 0.5 & 4.4 & 4.6 & 4.57 & 0.09 & 4.73 & 4.94 & 4.84 & 0.09 & 4.70 & 5.60 & 5.28 & 0.50 \\
\hline Yeas & 3 & 3.1 & 3.07 & 0.0 & & 3. & 3.06 & 0.1 & 3. & 3. & 3. & & .23 & 8 & 06 & 0.10 \\
\hline S. aure & 1.6 & 3.47 & 2.33 & 0.84 & & 1.78 & 1.75 & 0.03 & 1.7 & 3.48 & 2.65 & 0.82 & 1.89 & 1.97 & 1.93 & 0.05 \\
\hline Ila sp. (log cfu/g) & ND & & ND & & & & & ND & & & & & & & & ND \\
\hline E. coli $(\log \mathrm{cfu} / \mathrm{g})$ & ND & ND & ND & ND & ND & ND & ND & ND & 1.18 & 2.34 & 1.70 & 0.59 & 1.03 & 1.91 & 1.23 & 0.01 \\
\hline
\end{tabular}

FAM: Aerobic Mesophilic Flora

produced during breakdown of protein. No literature on the recommended $\mathrm{pH}$ range of African fermented fish products is available. This may cause optimal medium for pathogenic micro flora. So that, low $\mathrm{pH}$ reduce microorganism growth through formation of acid product. Our results are similar to those obtained by Majumdar et al. (2015) in Lona Ilish, an Indian fermented fish. Others studies (Majumdar et al., 2016) show that $\mathrm{pH}$ of fermented fish decrease with preservative period. According to Majumdar et al. (2015), decreasing of $\mathrm{pH}$ is due to formation of free fatty acids during fermentation.

Salt content: Salt content of Pelpeledgi is ranging from 2.42-3.48. Salt content of this fermented fish is low. This could be due to absence of salting step during processing. Thus, Pelpeledgi can be classified as free salt fermented fish product according to Sanni et al. (2002). Usually, African fermented fish are processing adding salt, consequently, these product content higher salts. Momone, a Ghanaian fermented fish product has also low salt content (Sanni et al., 2002). Lanhouin, a Benin fermented fish product has more salt content with 7.3\% (Anihouvi et al., 2006). Asian fermented fish have very high salt content ranging until $15.70 \%$ in case of Lona ilish (Majumdar and Basu, 2010).

Moisture: Moisture of the product was ranging from $10.22-19.11 \%$. There is a significant difference between samples of different areas. Samples with high moisture should be those which have been preserved for long period. According to Majumdar and Basu (2010), moisture of fermented fish increased with preservative period.

Water activity: The water activity of the whole samples varied from $0.70 \%$ (Blangoua) to $0.76 \%$ (Pous) and differed significantly $(\mathrm{p} \leq 0.05)$ between the samples (Table 2).
Microbiological profile of "Pelpeledgi": The results of microbiological analyzes performed on Pelpeledgi samples collected in local markets and at the processing and sale sites are summarized in Table 3. Total microbial count ranging from 6.41-7.70 log cfu/g for Blangoua and Pous samples, respectively. This total microbial count is high. Similar load were observed in Lanhouin and Momone with respectively load of 6-7 log cfu/g and 7.76-8.53 log cfu/g (Sanni et al., 2002; Anihouvi et al., 2007). The low salt content of Pelpeledgi and its high $\mathrm{pH}$ could assure adequate conditions for microorganism growth. Furthermore, Majumdar et al. (2015), indicated that microbial load of fermented fish increase with preservative periods and with moisture. For fresh fish, recommended load is 7 log cfu/g (Ojagh et al. 2010). Nevertheless no recommended limits for fermented fish were established until now. Lactic flora load of Pelpeledgi ranging from 4.57 (Pous) to $5.28 \mathrm{log} \mathrm{cfu} / \mathrm{g}$ (Blangoua), Bacillus load for Pelpeledgi samples ranging from 3.47-4.85 log cfu/g for Blangoua and Pous, respectively. Many studies on fermented fish products revealed occurrence and also prominence of mesophilic spores of Bacillus. Lactic flora and Bacillus seems to be the predominant flora on Pelpeledgi. Yeast and moulds were ranging from 3.06 (Blangoua and Pous) to $3.10 \mathrm{log} \mathrm{cfu} / \mathrm{g}$ for Lagdo. Our results are different from those obtained by Anihouvi et al. (2007) on Lanhouin. Total coliform were high and present in all Pelpeledgi samples, ranging from 3.47 (Blangoua) to $4.85 \mathrm{log} \mathrm{cfu} / \mathrm{g}$ (Pous), Staphylococcus aureus load ranging from 1.75-2.65 log cfu/g for Pous and Lagdo, respectively. All samples of Pelpeledgi contained S. aureus and only samples of certain areas contained E. coli into the fish product. This is a potential risk for consumer. So, traditional process technology of Pelpeledgi may have some HACCP points like utilization of river's water, handling without washing hands. So, then, Pelpeledgi process should be improved for better quality product. 
Agric. J., 14 (6): 123-131, 2019

Table 4: Sensory evaluation of Pelpeledgi samples

\begin{tabular}{|c|c|c|c|c|c|}
\hline \multirow[b]{2}{*}{ Samples of different areas } & \multicolumn{5}{|l|}{ Factor } \\
\hline & Aroma & Color & Texture & Taste & General appreciation \\
\hline Blangoua & $8.10 \pm 1.50^{c}$ & $7.5 \pm 0.71^{b}$ & $7.55 \pm 1.50^{\mathrm{b}}$ & $7.95 \pm 1.19^{b}$ & $7.85 \pm 0.60^{\mathrm{b}}$ \\
\hline Lagdo & $6.90 \pm 1.45^{\mathrm{b}}$ & $7.40 \pm 0.70^{\mathrm{b}}$ & $6.80 \pm 1.32^{\mathrm{b}}$ & $6.10 \pm 1.61^{\mathrm{a}}$ & $6.52 \pm 1.49^{\mathrm{a}}$ \\
\hline Maga & $5.95 \pm 1.16^{\mathrm{ab}}$ & $5.80 \pm 0.92^{\mathrm{a}}$ & $6.30 \pm 0.98^{\mathrm{a}}$ & $6.05 \pm 0.96^{\mathrm{a}}$ & $6.55 \pm 0.76^{\mathrm{a}}$ \\
\hline Pous & $5.65 \pm 0.75^{\mathrm{a}}$ & $5.80 \pm 0.92^{\mathrm{a}}$ & $6.10 \pm 0.74^{\mathrm{a}}$ & $6.00 \pm 1.25^{\mathrm{a}}$ & $6.05 \pm 0.68^{\mathrm{a}}$ \\
\hline
\end{tabular}

Salmonella sp. was not detected in any samples. Absence of $E$. coli in certain samples despite of utilization of polluted water should be laid to inhibitor action. According to Fay and Farias (1976), some compounds of free fatty acids play inhibitor action against pathogenic microorganisms like E. coli.

Sensory attribute of Pelpeledgi: The general appreciation of the fermented fish product ranging from 6.05-7.85 for Maga and Blangoua, respectively. All Pelpeledgi samples are accepted by panelists (Table 4). Our studies are similar to those obtained by Ahmed (1976), Youssef (1998), Sayed (2008), Ismail et al. (2015) who revealed that most salted fish samples they examined were physically normal. The most appreciate sample is from Blangoua area with the best aroma characteristic taste. Thus odor seems to be the most appreciated characteristic. Blangoua Pelpeledgi sample is also those which have high load of microbial (7.7 log cfu/g) and lactic acid bacteria (5, $28 \mathrm{log} \mathrm{cfu} / \mathrm{g})$. Microorganisms could play a fundamental role in fermentation process of Pelpeledgi, contributing for production of substances responsible for unique odor of this Cameroonian fermented fish product.

Many studies related to fermented fish like Shidal, Phassya shidal, Budu, Chapa shutki, Lona ilish, Puntius sophore (Muzaddadi and Basu, 2003; Majumdar, 2007) in South West Asia region and in Africa, like Momone in Ghana, Lanhouin in Benin, Guej in Senegal, Adjuevean in Ivory Coast (Kouakou et al., 2012; Sanni et al., 2002; Anihouvi et al., 2006) were conducted including nutritional aspects (Kouakou et al., 2012; Sanni et al., 2002; Anihouvi et al., 2006; Muzaddadi and Basu, 2003; Majumdar, 2007). These investigations show substantial nutritional potential of fermented fish and diversified microorganisms. High level of protein (33.20-45\%); fats (15-18\%); ash (10-15\%) were obtained (Anihouvi et al., 2006). Total microbial count was sometime high; Main microorganisms were lactic acid bacteria, Bacillus, Staphylococci, Micrococci and rarely yeast and moulds (Anihouvi et al., 2012). Technological properties of many strains were evaluated, showing interesting proteolytic, lipolytic and glucosidic activities (Sanni et al., 2002). Furthermore, some studies used specific bacterial strains for improvement of these fish product (Anihouvi et al., 2012). In spite of these interesting nutritional aspects and diversified microflora, occurrence of pathogens microorganisms and strains indicating fecal contamination are often observed
(Kouakou et al., 2012; Sanni et al., 2002; Anihouvi et al., 2007). It is case of $S$. aureus, Clostridium, Salmonella, Shigella, Bacillus cereus and E. coli (Kouakou et al., 2012). Seldom, fermented fish are processing under spontaneous fermentation, uncontrolled and no standardize conditions (Kakati and Goswami, 2013; Anihouvi et al., 2006). The uncontrolled processing may sometime cause formation of toxicologic coumpounds such as biogenic amine in general and particularly histamine. According to Soni and Sandhu (1990), the final characteristics of fermented foods are mainly due to its process.

\section{CONCLUSION}

The study shows that Pelpeledgi is known, very consumed and appreciated by majority of inhabitants of north region of Cameroon. Traditional technology processing is transmitted through generation from father to children. It can be classified as free salt fermented dry fish, so that, none salting step involve during process. Processing steps of Pelpeledgi comprises catching, washing, gutting, fermentation during 6-48 h and sun drying for 3-5 days. Controls critical points such as polluted river's water, unsterile utensils used, exposition to diversified contamination during processing, transport and on markets exist. The $\mathrm{pH}$ of Pelpeledgi is high and salt content is low. Total mesophilic flora is high in all samples. Yeast, moulds, E. coli, Salmonella were absents. Lactic acid bacteria and Bacillus is among predominant microorganism and seems to play a fundamental role in Pelpeledgi fermentation process. Pathogenic microorganisms were detected (total coliform and $S$. aureus), showing potential risk for consumer. Hence, in spite of it diversified microbial profile, further studies are essentials in order to do a HACCP on the product and apply a bacterial starter culture to obtain a better Pelpeledgi for consumers. It is therefore, important that actions be taken to improve the situation.

\section{REFERENCES}

AOAC., 2000. Official Methods of Analysis. 17th Edn., Association of Official Analytical Chemists, Arlington, VA., USA.

Ahmed, H.Y., 1976. Studies on the sanitary improvements of locally manufactured salted fish. Ph.D. Thesis, Assiut University, Asyut, Egypt. 
Agric. J., 14 (6): 123-131, 2019

Anihouvi, V., G.S. Ayernor, J.D. Hounhouigan and E. Sakyi-Dawson, 2006. Quality characteristics of Lanhouin: A traditional processed fermented fish product in the Republic of Benin. Afr. J. Food Agric. Nutr. Dev., 6: 1-15.

Anihouvi, V.B., E. Sakyi-Dawson, G.S. Ayernor and J.D. Hounhouigan, 2007. Microbiological changes in naturally fermented cassava fish (Pseudotolithus sp.) for Lanhouin production. Int. J. Food Microbiol., 116: 287-291.

Anihouvi, V.B., J.M. Kindossi and J.D. Hounhouigan, 2012. Processing and quality characteristics of some major fermented fish products from Africa: a critical review. Int. Res. J. Biol. Sci., 1: 72-84.

Belitz, H.D., W. Chen, H. Jugel, R. Treleano, H. Wieser, J. Gasteiger and M. Marsili, 1979. Sweet and Bitter Compounds: Structure and Taste Relationship. In: Food Taste Chemistry, Boudreau, J.C. (Ed.). Am. Chemical Society, USA., pp: 93-131.

Bene, C. and S. Heck, 2005. Fish and food security in Africa. NAGA WorldFish Center Q., 28: 8-13.

Bose, M.L. and M.M. Dey, 2007. Food and nutritional security in Bangladesh: Going beyond carbohydrate counts. Agric. Econ. Res. Rev., 20: 203-225.

Chiwaula, L.S., R. Witt and H. Waibel, 2011. An asset-based approach to vulnerability: The case of small-scale fishing areas in Cameroon and Nigeria. J. Dev. Stud., 47: 338-353.

Essuman, K.M., 1992. Fermented fish in Africa. A study on processing, marketing and consumption. FAO Fisheries Technical Paper, 329. FAO, Rome, pp: 80.

FAO., 2009. Low-income food-deficit countries 2009: FAO country profiles. FAO, Rome, Italy.

Fay, J.P. and R.N. Farias, 1976. Chilling cells enhances the bactericidal action of fatty acids on Escherichia coli. Appl. Environ. Microbiol., 31: 153-157.

Feka, N.Z. and M.G. Manzano, 2008. The implications of wood exploitation for fish smoking on mangrove ecosystem conservation in the South West Province, Cameroon. Trop. Conserv. Sci., 1: 222-241.

Gram, L. and H.H. Huss, 2000. Fresh and Processed Fish and Shellfish. In: The Microbiological Safety and Quality of Food, Lund, B.M., T.C. Baird-Parker and G.W. Gould (Eds.). Vol. I. Aspen Publishers Inc., Gaithersburg, Marylan, pp: 472-506.

Ismail, H., M. Ismail, H. Ahmed and A. Youssef, 2015. Mycological evaluation of salted Hydrocynus forskalii fish in Assiut governorate. Assiut Vet. Med. J., 61: 187-196.

Kakati, B.K. and U.C. Goswami, 2013. Characterization of the traditional fermented fish product Shidol of Northeast India prepared from Puntius sophore and Setipinna phasa. J. Food Sci. Technol., 53: 401-410.
Kawarazuka, N. and C. Bene, 2010. Linking small-scale fisheries and aquaculture to household nutritional security: An overview. Food Secur., 2: 343-357.

Kouakou, A.C., M. Cisse, E. Kossonou, D.B. Kouakou, M.K. Dje and D. Montet, 2012. Identification of yeasts associated with the fermented fish, adjuevan, of Ivory Coast by using the molecular technique of PCR-Denaturing Gradient Gel Electrophoresis (DGGE). Afr. J. Microbiol. Res., 6: 4138-4145.

Loring, P.A., D.V. Fazzino, M. Agapito, R. Chuenpagdee, G. Gannon and M. Isaacs, 2019. Fish and Food Security in Small-Scale Fisheries. In: Transdisciplinarity for Small-Scale Fisheries Governance, Chuenpagdee, R. and S. Jentoft (Eds.). Springer, Cham, Switzerland, ISBN: 978-3-319-94937-6, pp: 55-73.

Majumdar, R.K. and S. Basu, 2010. Characterization of the traditional fermented fish product Lona ilish of Northeast India. Indian J. Trad. Knowle, 9: 453-458.

Majumdar, R.K., 2007. Phassya Shidal-a traditional fermented fish product of NE India. Fishing Chimes, 27: 30-31.

Majumdar, R.K., D. Roy, S. Bejjanki and N. Bhaskar, 2016. Chemical and microbial properties of shidal, a traditional fermented fish of Northeast India. J. Food Sci. Technol., 53: 401-410.

Majumdar, R.K., S.K. Bejjanki, D. Roy, S. Shitole, A. Saha and B. Narayan, 2015. Biochemical and microbial characterization of Ngari and Hentaak-traditional fermented fish products of India. J. Food Sci. Technol., 52: 8284-8291.

Matoba, T. and T. Hata, 1972. Relationship between bitterness of peptides and their chemical structures. Agric. Biol. Chem., 36: 1423-1431.

Muzaddadi, A.U. and S. Basu, 2003. Seedal-an indigenous fermented fishery product of North-East India. Fishing Chimes, 23: 30-32.

Noman, M., M. Mohsin, G.A.S. Bukhari, Z. Hamid and A. Mehak, 2019. Small-scale fisheries: Overview, importance, vulnerabilities and management. Indian J. Geo-Marine Sci., 48: 183-192.

Ojagh, S.M., M. Rezaei, S.H. Razavi and S.M.H. Hosseini, 2010. Effect of chitosan coatings enriched with cinnamon oil on the quality of refrigerated rainbow trout. Food Chem., 120: 193-198.

Rousseau, Y., R.A. Watson, J.L. Blanchard and E.A. Fulton, 2019. Defining global artisanal fisheries. Marine Policy, Vol. 108, 10.1016/j.marpol.2019.103634 
Sanni, A.I., M. Asiedu and G.S. Ayernor, 2002. Microflora and chemical composition of momoni, a Ghanaian fermented fish condiment. J. Food Compos. Anal., 15: 577-583.

Sayed, S.M., 2008. Egyptian traditional salted fishes: Processing technology and quality control monitoring. Ph.D. Thesis, Assiut University, Asyut, Egypt.

Sefa-Dedeh, S., 1995. Process and product characteristics of agbelima, a fermented cassava product. Trop. Sci., 35: 359-364.

Singh, A.K. and P. Sharma, 2018. Implications of climatic and non-climatic variables on food security in developing economies: A conceptual review. MOJ. Food Proc. Technol., 6: 1-12.
Soni, S.K. and D.K. Sandhu, 1990. Indian fermented foods: Microbiological and biochemical aspects. Indian J. Microbiol., 30: 135-157.

Yang, J. and J. Lee, 2019. Application of sensory descriptive analysis and consumer studies to investigate traditional and authentic foods: A review. Foods, Vol. 8, No. 2. 10.3390/foods8020054

Yankah, V.V., T. Ohshima and C. Koizumi, 1993. Effects of processing and storage on some chemical characteristics and lipid composition of a Ghanaian fermented fish product. J. Sci. Food Agric., 63: 227-235.

Youssef, H.H.E., 1998. Mycological status of Moloha, Smoked herring and frozen mackerel fish in Assuit province. Ph.D. Thesis, Assiut University, Egypt. 